\title{
Masalah Konsentrasi Industri dan Dampaknya pada Perekonomian Indonesia
}

\author{
Oleh : Edy Suandi Hamid
}

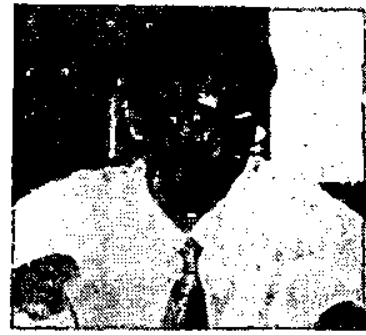

Edy Suandl Hamld, adalah dosen negeri yang dipekerjakan pada FE UII lulus dari FE UGM (1983) dan Faculty of Economics Thammasat University (1990). Saat ini, disamping menjabat Sekretaris Umum Ikatan Sarjana Ekonomilndonesia DIY, juga sebagai Sekretaris Eksekutif pada Institute for Development Economic Analysis (IDEA). Disamping pernah. menjabat sebagai PD I dan Dekan FÉ UII, juga pernah bekerja pada Lembaga Ekonomi dan Kemasyarakatan (LEKNAS - LIPI) dan Redaktur pada SKH Kedaulatan Rakyat. Disamping banyak mengadakan penelitian tentang ekonomi pedesaan dan ekonomi regional, juga menulis beberapa buku yang berkaitan dengan bidang ekonomi.

\section{Gambaran Umum}

Perbincangan tentang masalah yang berkaitan dengan adanya suatu konsentrasi ekonomi yang tinggi pada berbagai sektor ekonomi di Indonesia, akhir-akhirini seakan sama dengan membicarakan persoalan sehari-hari yang ada di masyarakat. Topik tersebut tak hanya menjadi perbincangan kalangan akademis ataupun pengamat ekonomi, namun meluas menjadi pembicaraan publik, sebagai akibat seringnya isyu tersebut muncul di media massa. Hal ini tidak saja dikaitkan dengan perilaku industri yang mempunyai konsentrasi pasar yang tinggi, yang dinilai telah banyak menimbulkan kenugian pada konsumen, melainkan juga berkaitan dengan fasilitas yang diterimanya dari pemerintah, baik itu berupa proteksi, ataupun subsidi.

Yang terakhir misalnya, merebak sinyalemen tentang subsidi yang telah diterima oleh PT Bogasari Flour Mills, sebuah perusahaan yang sahamnya dimiliki oleh konglomerat Liem Sioe Liong dan Sudwikatmono. Menurut publikasi dari Indef, perusahaan tersebut "disinyalir" tahun 1994 saja telah menikmati subsidi dari transasksi tepung terigunya dengan Bulog sebanyak Rp. 760 milyar. Ini baru satu tahun, padahal hak yang hampir monopoli dari bogasari untuk membeli impor terigu Bülog tersebutsudah belasantahun. Sekedar perbandingan, dana ini hampir 1,5 kali dana 
pengeluaran pembangunan untuk sèmua sektor perdagangan, pengembangan usaha nasional dan koperasi dalam tahun anggaran 1995/1996 ini yang "cuma" Rp. 533,7 milyar, dan lebih dari $1,5 \mathrm{kali}$ dibandingkan untuk Inpres Desa Tertinggal yang setahunnya "hanya" Rp. 400milyar. Adanya subsidi tersebut agaknya tidak dibantah oleh pèmerintah/Bulog, hanya saja angkanya tidak sebesar yang dikemukakan Indef tersebut. Walaupun angka-angka tersebut masih bisa dipertanyakan, namun hal ini telah menunjukkan adanya praktek ekonomi yang tidak fairyang terkait dengan pelaku industri kita.

Sebelumnya juga sudah muncul "gugatan" dari Bank Dunia tentang adanya praktek kartel dan sejenisnya, yang bahkan disinyalir justru- tercipta dari kebijakan pemerintah sendiri. Lembaga yang mempunyai divisi-divisi pengkajian ekonomi yang dikenal memiliki data akurat dan analisis yang cukup mumpuni pula, menyatakan dalam salah satu laporan yang dipublikasikan baru-baru ini bahwa "beberapa industri di Indonesia sudah beroperasi miripkartel, sehingga merugikan konsumen yang harus membayar produk sejenis lebih mahal dibanding luar negeri". Sebagian contoh ditunjukkan oleh Bank Dunia antara lain adalah industri semen, kertas, dan bubur kertas (pulp).

Pada sektor industri, angka perhitungan Dr. Nurimansyah Hasibuan menunjukkan konsentrasi industri yang oligopolistik ini sudah mencapai $72 \%$ dari total industri yang ada. Angka ini, 18 tahun yang lalu, masih 67\% (Republika, 8/5/95. hal. 1). Angka ini kiranya sejalan dengan gambaran faktual yang ada. Secara kasar mata kita bisa melihat bahwa segelintir pengusaha masuk dan menguasai berbagai sektor bisnis. Setiap celah bisnis yang ada. entah itu terkait atau tidak terkait dengan core business-nya, dimasuki oleh konglomerat.

Tampaknya perbincangan yang berkaitan dengan konsentrasi industri yang tinggi pada berbagai sektor ekonomi ini belum akan berhenti. Adanya globalisasi ekonomidunia ataupun arah perekonomian yang menuju pada persaingan bebas, telah menyebabkan pembicaraan mengenai hal tersebut menjadi kian bergema. Hal ini dikarenakan pada era persaingan bebas tersebut dikhawatirkan industri Indonesia yang berkembang karena berbagai insentif ataupun persaingan tidak jujur tersebut akan kalah bersaing dengan industri dari luar yang lebihefisien. Oleh karena itu, menjadi wajar kalau gugatan atas praktek industri yang demikian menjadi terus bermunculan.

Secara garis besar konsentrasi industri yang banyak diperbincangkan tersebut, dari sisi produsen/penjual, adalah berkaitan dengan struktur pasar monopoli, oligopoli serta kartel. Monopoli merupakan bentuk pasar yang hanya dikuasai satu produsen, sedangkan oligopoli ada beberapa atau segelintir produsen yang menguasai sebagian besarpasar. Sedangkan kartel juga terjadi dalam pasar oligopoli, dimana perusahaan-perusahaan besar. yang menguasai pasar tersebut mengadakan kolusi atau perjanjian yang berkailan dengàn produksi,pembagian pasar. penetapan harga dan lainnya, yang umumnya berorientasi pada upaya pencapaian kebutuhan maksimal dari praktek "joint profit maximization": 
Beberapa Kasus Konsentrasi Industri

Secara teoritik terdapat beberapa faktor yang menjadi penyebab munculnya konsentrasi pasar, baik itu berbentuk monopolimaupun oligopoli. Faktortersebut antara lain yang pertama adalah penguasaan teknologi atau teknik produksi tertentu, sehingga dapat memenangkan persaingan dalam pasar, yang menyebabkan pesaing ' lain yang kalah efisien sulit masuk ke pasar. $K e d u a$, adanya perlindungan dari. pemerintah, sehingga menutup atau menyulitkan peluang bagi pesaing untuk terjun dalam usaha yang sama. Perlindungan ini dapat berupa perolehan bahan baku. tarif bea masuk, dan sebagainya. Ketiga, adanya kolusi dari segelintir pelaku ekonomi yang ada di pasar. Keempat, adanya hak patent yang diberikan untuk. jangka waktu tertentu sebagai akibat penemuan atas produk spesifik tertentu. Kelima, adanya merger dari beberapa perusahaan, sehingga penguasaan atas pasar dari beberapa perusahaan yang merger tểsebut kian besar. Keenam, adanya skala produksi yang besar, yang ditopang pula olehproses produksi yang efisien, sehingga menyulitkan pesaing untuk memasuki pasar yang sama (lihat, misalnya Nurimansyah Hasibuan 1993 dan 1995).

Dari faktor-faktor tersebut secara garis besar dapat dikatakan bahwa konsentrasi pasar ini dapat terjadi karena memang kemampuan daya saing yang tinggi dari suatu perusahaan, karena praktek yang tidak fair, serta karena adanya fasilitas yang diberikan oleh pemerintah. Untuk yang pertama, kiranya bisa dipahami. Adanya kemampuan penguasaan pasar karena kemampuan untukmenekan biaya produksi menjadi sangat rendah, misalnya, sehingga dapat menjual output dengan harga murah, jelas tidak akan merugikan konsumen. Namun jika konsentrasi pasar apakah itu monopoli atau oligopoli karena kolusi dan fasilitas; maka dampaknya akan sangat menugikan konsumen. Praktek seperti inilah yang sekarang ramai dibicarakan, dan memang tidak bisá dibiarkan terus berlanut. Hal ini bukan saja berakibat ruginya konsumenkarena terpaksa membayar harga yang mahal atas sesuatu produk, tetapi juga dalam jangka panjang akan merugikan ekonominasional karena dayasaing industri yang demikian akan sangat rendah. Akibatnya, apabila saatnya kita sudah masuk dalam persaingan terbuka nantinya, maka industri ini akan dapat runtuh, yang berarti pula lepasnya pasar domestik ke tangan produsen luar negeri.

Strukturpasaryangmonopolistik dan oligopolistik tampak pada tujuh dari sembilan subsektor industri kita. Sebagaimana konvensi intemasional yang dipegang kebanyakan para ekonom, suatu industri dapat dikatakan memiliki struktur oligopolistik manakala empat perusahaan terbesar dalam industri tersebut menguasai lebih dari $40 \%$ dari pasar.yang ada. Dengan menggunakan ukuran ini, dapat dilihat bagaimana tujuh dari sembilan subsektor - industrị (dilihat dari standar ISIC dua digit level) kita sudah termasuk yang konsentrasinýa tinggi atau berbentuk oligopolistik. Bahkan lima dari sembilan subsektor industri tersebut, yakni makanan minuman, tembakau, kertas, barang galian bukan logam, logam dasar, dan barang dari logam, mesin dan peralatannya, memiliki rasio konsentrasi di atas 50 (Tabel 1). 
Namun demikian, secara rata-rata tingkat perusahaan yang sama mendirikan beberapa konsentrasi tersebut telah mengalami perusahaan yangberoperasi padasubsektor penurunan dari 49.5 persen menjadi 47,1 industri yang sama, atau adanya kartel dari persen.

perusahaan besar yang ada (Iqbal, 1995.

\section{Tabel 1:}

Tingkat Konsentrasi dalam Industri Manufaktur 1985-1991

(Pangsa 4 Perusahaan Terbesar: dalam Persen)

\begin{tabular}{l|l|c|c}
\hline $\begin{array}{l}\text { Kode } \\
\text { ISIC }\end{array}$ & \multicolumn{1}{|c|}{ Subsektor } & 1985 & 1991 \\
\hline & & & \\
31 & Makanan, minuman tembakau & 59,1 & 61,5 \\
32 & Tekstil, pakaian jadi, kulit & 24,9 & 24,0 \\
33 & Produk kayu & 13,4 & 15,9 \\
34 & Kertas & 43,8 & 50,2 \\
35 & Kimia & 76,4 & 44,6 \\
36 & Barang galian bukan logam & 82,7 & 58,1 \\
37 & Logam dasar & 49,7 & 71,8 \\
38 & Brg dari logam \& peralatannya & 71,9 & 57,4 \\
39 & Pengolahan lain & $\cdot$ & 49,0 \\
& & 49,5 & 47,1 \\
\hline
\end{tabular}

Sumber: BPS, backcast data lihat lqbal, Farrukh (1995, p. 17)

Tingkat konsentrasi industri yang terjadi di Indonesia ini sudah terbilang cukup tinggi. Di negara-negara industri, seperti Inggris dan Amerika Serikat, angkanya masing-masing adalah 22 persen dan 36 persen, sementara Indonesia adalah 47,1 persen. Walaupun begitu, data yang diolah BPS itu harus dilihat secara berhatihati. Sangat mungkin konsentrasi sebenarnya, jika dilihat dari kepemilikannya, lebih tinggi dari yang tertera di atas. Ini mengingat pemilik hal.16). Dengan kata lain, sangat mungkin data tersebut underestimate jika secara cermat dilihat dari segi kepemilikan perusahaan industri tersebut.

Sementara jika dilihat dari ISIC 3 digit level, sebanyak 16 dari 29 subsektor industri ini juga memiliki tingkat konsentrasi diatas 50 persen (Tabel 2). Ini memberikan uraianlebih detail tentang jenis komoditi yang konsentrasinya tinggi tersebut. 
UNISIA, NO. 27 TAHUN XV TRIWULAN IIi - 1995

Tạbel 2 : Index Konsentrasi Industri 1992 (Dalam 3 Digiı ISIC)

\begin{tabular}{|c|c|c|c|}
\hline ISIC & INDUSTRY & CR4 & CR4 $>50 \%$ \\
\hline 311 & Makanan : & $\cdot 0,56$ & $>50 \%$ \\
\hline 312 & Pengolahan Makanan & 0.40 & \\
\hline 313 & Minuman & 0.81 & $>50 \%$ \\
\hline 314 & Pengolahan Tembakau & 0.74 & $>50 \%$ \\
\hline 321 & Textile & 0.49 & ר \\
\hline 322 & Pakaian Jadi & 0.46 & \\
\hline 323 & Kulit \& Brg. Dari Kulit & 0.33 & . \\
\hline 324 & Alas Kaki & 0.20 & \\
\hline $331^{-}$ & Kayu, bambu, rotan, rumput dsb & 0.32 & \\
\hline 332 & -Furniture dan fixtures' & 0.57 & $>50 \%$ \\
\hline 341 & Kertas dan Brg dari Kertas & 0.54 & $>50 \%$ \\
\hline 342 & Percetakan dan penerbitan & 0.38 & \\
\hline 351 & Bahañ kimia industri & 0.51 & $>50 \%$ \\
\hline 352 & Kimia lainnya & 0.56 & $>50 \%$ \\
\hline 353 & Pemurnian dan pengilangan minyak bumi & 1.00 & $>50 \%$ \\
\hline 355 & Karet dan barang karet & 0.58 & $>50 \%$ \\
\hline 356 & Barang plastik & 0.42 & $\therefore \quad$. \\
\hline 361 & Porselin & 0.38 & - \\
\hline 362 & Gelas dan barang dari gelas & 0.84 & $>50 \%$ \\
\hline 363 & Semen \& Brg. semen, kapur \& brg kapur & .0 .39 & \\
\hline 364 & Pengolahan tanah liat & 0.55 & $>50 \%$ \\
\hline 369 & Brg. Galian bukan logam - . & 0.24 & \\
\hline 371 & Logam dasar besi dan baja & 0.56 & $>50 \%$ \\
\hline 381 & Barang dari logam, kecuali mesin \& alat & 0.56 & $>50 \%$ \\
\hline 382 & Mesin dan perlengkapan bukan listrik & 0.32 & 2 \\
\hline 383 & Mesin, alat dan alat listrik & 0.35 & \\
\hline 384 & Alat angkutan & 0.68 & $>50 \%$ \\
\hline 385 & alà profesional, ilmu pengetahuan, dil & 0.71 & $>50 \%$ \\
\hline 390 & Pengolahan lainnya & 0.60 & $>50 \%$ \\
\hline
\end{tabular}

Sumber : PAU - UGM

Sebagaimana dilaporkan Bank , restriksi dalam pasar komoditi tersebut. Dunia, beberapa sektor industri di Indone- Adapun jenis restriksi atau hambatan dan sia telah terjadi konsentrasi yang tinggi, sektor industrinya dapat dilihat dalam Tabel yang antara lain terjadi karena adanya 3 . 
Tabel 3: Restriksi dalam Persaingan pasar Domestik

\begin{tabular}{ll}
\hline Jenis Restriksi & Sektor Industri \\
\hline Kartel & Semen, kaca, plywood, kertas \\
Kontrol harga & Semen, gula, beras, mobil \\
Kontrol masuk/keluar & Plywood dan mobil \\
Pasar & \\
Lisensi khusus & Pemasarancengkeh, tepung terigu \\
Perusahaan negara & Baja, pupuk \\
\hline
\end{tabular}

Sumber: lqbal, Farrukh, "Deregulation and Development in Indonesia", makalah pada seminar Building on Success: Maxi-mizing the Gains from Deregulation, Jakarta, 1995

Hambatan-hambatan yang menutup peluang masuknya pesaing baru ini tidak hanya dilakukan oleh perusahaan swasta sendiri, yang secara langsung lewat asosiasinya tanpa ada sangsi dari pemerintah ini lewat berbagai kolusi bisnis, melainkan dilakukan oleh pemerintah pusat dan daerah (Iqbal, Farrukh, Hal.14). Sinyalemen dari masalah yang dikemukakanstaf Bank Dunia ini, yang juga muncul dalam laporań resmi Bank Dunia tersebut, sebetulnya bukanlah sesuatu yang baru. Hal yang sama sudah lama "digugat" oleh kalangan ekonom ataupun pengamat ekonomi nasional, namun respon atas masalah tersebut bergema lain setelah dikemukakan Bank Dunia.

Walau kita mengetahui pernyataan tersebut bukan sesuatu yang baru, lantas mengapa terkesan sangat menarik perhatian?

Paling tidak ada dua hal yang menyebabkan hal tersebut memicu komentar berbagai pihak. Pertama, karena yang mengemukakannya adalah Bank Dunia, suatu lembaga yang suaranya dapat mempengaruhi kebijakan pemerintah, ataupun pihák lain yang berkaitan dengan Indonesia. Apąlagi pemyataan ini muncul menjelang sidang CGI yang akan membicarakan permohonan pinjaman (utang luar negeri Indonesia).

Kedua, pemyataan Bank Dunia itu menjadi menarik, aktual dan bermakna. karena secara tersurat Bank Dunia menyatakan bahwa praktek kartel tersebut "didukung oleh kebijaksanaan pemerintah, dan diantara kartel tersebut adalah' Badan Usaha Milik Negara (BUMN)". Ini sebenamya sangat ironis dengan kebijakan yang ditempuh oleh banyak negara dunia sebagaimana dicontohkan diatas yang pemerintahnya justru menerapkan sangsi hukum bagi yang melakukan praktek kartel tersebut. Praktek kartel selayaknyadilarang karena memang dapat merugikan konsumen dan mengakibatkan alokasi sumber ekonomi secara nasional tidak optimal.

Dalam teori-teori ekonomi selalu dikemukakan bahwa praktek kartel akan memungkinkan bagi produsen menerapkan harga yang tinggi dari yang seharusnya (harga jual lebih besar dibandingkan biaya produksi rata-rata per unit). Harga ini juga jauh diatas tingkat harga di pasar dunia, jika mereka juga mendapatkan proteksi, sehingga membebani konsumen secara umum. Sasarannya adalah untuk mengejar keuntungan yang maksimum, tanpa melihat dampaknya bagi kepentingan masyarakat luas atau ekonomi nasional.

Akibat lain, alokasi sumberdaya juga menjadi tidak efisien jika produsen membatasi diri pada jumlah output tertentu dalam rangka "nemelihara" harga yang' tinggi tersebut untuk memperoleh "supernomal profit" atau keuntungan di atas normal. Produsen sebenarnya dapat 
memproduksi lebih banyak tanpa harus merugi, namun hal demikian tidak dilakukannya. Ini berarti output di masyarakat menjadi berkurang, atau seçara makro dapat dikatakan menurunkan kesejahteraan masyarakat.

Akibat-akibat dari Konsentrasi Industri. Adanya konsentrasi industri sebetulnya tidaklah selalu berakibat jelek bagi suatu perekonomian, sepanjang industri tersebut dapat bekerja secaraefisien dan tidak memanfaatkan konsentrasi yang tinggi untuk 'mengeksploitasi konsumen dengan harga produk yang tinggi. Hal ini umumnya dapat terjadi apabila konsentrasi tersebut diperoleh melalui suatu proses persaingan alamiah (natural competition), yang dengan kompetisi yang sehat telah melahirkan hanya satu atau beberapa perusahaan saja yang mendominasi pasar. Namun demikian persoalan yang sering munculadalah terjadinya suatu konsentrasi yang berbentuk monopoli ataupunoligopoli karena berbagai perlindungan ataupun fasilitas dari birokrasi serta adanya kolusi bisnis yang mempersempit atau menghalangi masuknya pesaing-pesaing baru ke dalam pasar.

Di samping adanya akibat-akibat yang dapat menimbulkan kerugian pada konsumen karena tinggi harga, konsentrasi yang menekan munculnya persaingan banyak menimbulkan inefisiensi dalam perekonomian. Mereka juga menghindari kapasitas penuh untuk menekan. Sebagai matarantai adanya ketidakefisienan tersebut maka industri yang demikian membutuhkan proteksi-proteksi terhadap pesaing dari luar dan sangat rendah kemampuan ekspomya. Hal ini dapat dilihat pada beberapa kelompok komoditi yang diproduksikan, yang konsentrasi pada dalam negerinya tinggi kébanyakaǹ orientasi ke pasar ekspomya rendah.

Täbel 4: Tingkat Konsentrasi dan Orientasi Ekspor

\begin{tabular}{l|l|l}
\hline $\begin{array}{l}\text { Tingkat } \\
\text { Konsentrasi }\end{array}$ & $\begin{array}{l}\text { Orientasi ekspor } \\
\text { tinggi }\end{array}$ & $\begin{array}{l}\text { Orientasi ekspor } \\
\text { rendah }\end{array}$ \\
\hline Tinggi & & $\begin{array}{l}\text { Bukan logam } \\
\text { Barang dari logam } \\
\text { Kimia. } \\
\text { Kertas } \\
\text { Makanan' } \\
\text { Logam dasar }\end{array}$ \\
$\cdots, \quad$, & & \\
\hline Rendah & Barang dari kayu & \\
\hline
\end{tabular}

Keterangan: Konsentrasi tinggi apabila konsentrasi 4 perusahaan terbesar (1991) dari subsektor tersebut adalah lebih besar dari rata-rata tertimbang $47 \%$; Orientasi ekspor tinggi bila pangsa total outputyang diekspor lebih tinggi dibanding rata industri sebesar 25\% (1992)

Sumber: $\quad$ Iqbal, Farrukh, h.18

Dengan kondisi yang demikian dapat dibayangkan bahwa industri yang demikian akan sangat rentan dalam persaingan bebas, atau jika tidak ada proteksi dan fasilitás yang diberikan oleh pemerintah. Dengan tidak adanya suatu perlindungan berupa proteksi, kuota dan sejenisnya, maka buka saja akan sulit menembus pasar luarnegeri. karena dengan adanya AFTA, WTO, dan APEC, industri-industri kita nantinya harus siap bersaing dengan industri yang berasal dari negara lain, termasuk dari negara maju, yang sudah sangat terbiasa dengan budaya persaingan bebas dan berproduksi secara efisien.' 


\section{Penutup}

Demikian gambaran tentang beberapa struktur industri kita, yang secara nyata memberikan gambaran adanya beberapa konsentrasi yang berimplikasi pada ketidakefisienan. Konsentrasi industri yang demikian, yang muncul karena adanya restriksi-restriksi innatural, perlu dirombak. Artinya, jika konsentrasi itu muncul karena kebijakan pemerintah, maka kebijakan tersebut perlu dirubah yang diarahkan pada pembukaan peluang bagi pesaing baru untuk terjun pada sektor-sektor tersebut. Namun demikian jika hal itu terjadi karena adanya praktek-praktek kolusi ataupun kerja sama yang tidak fair, maka perlu dipikirkan pula sangsi yang tegas kepada para pelakunya. Oleh karena itu, dibutuhkan pula perangkat hukumnya untuk mengambil tindakan tersebut.

Misalnya terhadap praktek-praktek kartel terselubung atau praktek beberapa industri sejenis yang melakukan kolusi sehingga dapat mengendalikan pasar. Tindakan tegas seperti ini sudah diterapkan di negara-negara kapitalis seperti USA sekalipun. Di Amerika Serikat tersebut, ada Sherman Act yangusianya sudah seabad (1890), yang isinya secara jelas melarang praktek kerja sama ataupun persekongkolan yang mengekang perdagangan, termassuk penetapan harga secara vertikal atau horisontal, pemboikotan bersama, pembagian pasar dan praktek-praktek dagang restriktif lainnya.

Di negara tetangga kita, Thailand, perundang-undangan mereka tentang penetapan harga dan antimonopoli (1979) juga menegáskan larangan tentang kolusi -bisnis, kesepakatan penetapan harga jual secara bersama, ataupun membagi-bagi dan mengalokasikan wilayah distributor produknya.

Itu hanya beberapa contoh saja. Ketentuan senada juga sudah sejak lama ada di negara-negara seperti Australia ataupun negara Eropa Barat. Pérserikatan Bangsa-Bangsa pun juga sudah memiliki ketentuan sejenis, yakni Resolusi PBB No. 35.65 tahun 1967 yang dikenal dengan The Set of Multilaterally Agreed Equitable Principles and Rules for the Control of Restrictive Business Practices. Namun demikian di tanah air kita hal ini masih menjadi perdebatani, karena aturan yang ada belum secara tegas mengatur aspekaspek yang berkaitan dengan praktek monopoli, oligopoli dan praktek bisnis yang tidak jujur lainnya.

\section{Daftar Pustaka}

Anggito Abimanyu, "Orientasi Usaha dan Kinerja Bisnis Konglomerat", pada Jurnal UNISIA, No. 25/1995.

Edy Suandi Hamid, "Perilaku Industri dan -Konglomerasidi Indonesia", pada Jumal UNISIA, No. 25/1995.

Edy Suandi Hamid, "Ekonomi Kerakyatan di Tengah Kecenderungan Keterbukaan Ekonomi", makalah pada forum Diskusi Panel Ekonomi Kerakyatan, yang diadakan harian Pikiran Rakyat, Bandung, 1975.

Edy Suandi Hamid, "Transformasi Struktural Pembangunan Ekonomi Indonesia", makalah pada formum Diskusi Panel 50 Tahun Indonesia Merdeka, FE UII, Yogyakatya, 1995.

Iqbal, Farnukh, "Deregulation and Development in Indonesia", makalah pada seminar Building on Success: Maximizing the Gains from deregulation, Jakarta, 1995. 
Kunio. Yoshira. The Rise of Ersatz Capitalism in Southeast Asia. Oxpord University Press. Singapore, 1988.

Lucky Sondakh, "Dcregulasi, Dayasaing dan Perekonomian Rakyat", makalah pada Sidang Pleno ISEI ke-8, Mandido, 1995.
Nurimansyah Hasibuan, Ekonomi Industri: Persaingan, Monopoli dan Deregulasi. LP3ES. Jakarta, 1995.

Rizal Ramli. "Inefisiensi Ekonomi Indonesia: Kinerja konseptual dan Perubahan Struktur Industri: makalah pada Sidang Pleno ISEI Ke-8, Manado, 1995. 